\title{
SEASONAL ABUNDANCE AND RELATIVE DENSITIES OF COCCINELLID SPECIES AND THEIR INSECT PARASITOIDS ON WHEAT PLANTS AT PILBES DISTRICT, SHARKIA GOVERNORATE, EGYPT
}

\author{
Faten G-E. Mohamed", K.A.A. Hammad, M.R.A. Hassan and M.A.I. Youssif \\ Plant Prot. Dept., Fac. Agric., Zagazig Univ., Egypt
}

Received: 31/05/2020; Accepted: 30/06/2020

\begin{abstract}
Survey and relative densities of coccinellid species and their parasitoids on wheat plants infesting with aphids at Pilbes district, Sharkia Governorate, Egypt was studied during 2015/162016/17 seasons. Summarized results show the following: Seven predaceous species belonging to family Coccinellidae viz., Coccinella undecimpunctata L., Coccinella septempunctata L., Coccinella 9-punctata L., Scymnus syriacus Mars, Scymnus interruptus (Goeze), Cydonia vicina isis Cr. and Cydonia vicina nilotica Muls were surveyed on wheat plants infesting with aphids. The general relative densities of the predators were $33.33,20.29,19.44,12.35,7.41,4.01$ and $2.47 \%$ of the total numbers of predators, respectively. C. undecimpunctata activity showed a distinct peak and two peaks of activity in the first and second seasons, respectively. The maximum total monthly counts of 83 and 77 predators were found during March, in the first and second seasons. Five species of hymenopterous parasitoids belong to three families were emerged from collected ladybeetles species, viz., Telenomus sp., Perilitus coccinellae (Schrank), Tetrastichus coccinellae Kurd., Tetrastichus principiae Domenichini and Tetrastichus sp. The egg parasitoid, Telenomus sp. came in the first rank, represented by $59.8 \%$, followed by the larval parasitoid $P$. coccinellae $14.6 \%$. The correlations between the total number of coccinellid predators and aphids were positive and highly significant in both seasons.
\end{abstract}

Key words: Coccinellid species, coccinellid parasitoids, parasitism, wheat plants.

\section{INTRODUCTION}

Coccinellidae are considered useful natural enemies feeding on phytophagous insect species and regulating their populations in many agricultural systems involving commercial crops (Obrycki et al., 2009). Many Coccinellidae species are promising predatory biocontrol agents for many phytophagous pests including aphids, scale insects, whiteflies, mites, Jassids, thrips, mealybugs and eggs of various lepidopterous insects (Hodek and Honek, 1996; Omkar and Srivastava, 2003; Silva et al., 2012; Vandereycken et al., 2015). Ladybeetles are commonly found in vegetation containing grasses and herbs, and are predacious in the adult and larval stage (Shehta, 2008). Coccinellidae species known as ladybeetle such as Coccinella, Cydonia, Hippodamia, Stethorus, Rodalia (=Vedalia), Scymnus and Cryptolaemus species (Brown, 2004; Zeynep et al., 2011; James et al., 2012). Several coccinellid species were recorded on different fields, vegetable and fruit crops in Egypt.

The aphids, Aphis craccivora Koch., Aphis gossypii (Glover) and Myzus persicae (Sülzer) constitute the food essential for the majority of Coccinellidae (Obreycki et al., 2009). For most agricultural systems, the augmentative releases and conservation techniques for ladybird beetles are greatly emphasized to maximize their uses in biological control (Rizvi et al., 1994). Ladybeetles are tools in various bioconrol strategies worldwide like classical inundative, inoculative and conservative

\footnotetext{
* Corresponding author: Tel. : +201289167262

E-mail address: keshk.faten@yahoo.com
} 
strategies (Obreycki and Kring, 1998; Weber and Lundgren, 2009). This family gained an interested role as important group of predators in the biological control of insect pests attacking different crop plants. Many coccinellid species were recorded associated with the pests in fields of different economic crops (Shalaby et al., 2008). Many attempts have been made by releasing some biocontrol agents, particularly common coccinellid species for controlling aphid species. In the fields, eggs, larvae, pupae and adults of coccinellids are attacked by several parasitoids which affected the effectiveness of the ladybird beetles (Keiko et al., 1995; Silva et al., 2012; Trouve et al., 2012; Richerson and Deloach, 2017). The present work aimed to study the following points.

1. Survey and relative densities of coccinellid species.

2. Seasonal abundance of the predominant coccinellid species in relation with prevailing temperatures and relative humidities.

3. Survey, relative densities and seasonal abundance of insect parasitoids associated with that coccinellid species in relation with prevailing temperatures and relative humidities.

\section{MATERIALS AND METHODS}

The present investigation was carried out at Bilbes district, Sharkia Governorate, Egypt during two wheat growing seasons of 2015-16 and 2016-17 to survey, relative densities and seasonal abundance of coccinellid species and their insect parasitoids.

The experimental area was about half faddan, was cultivated with wheat, Triticum astivum L., variety Sakha 69 and sown on $10^{\text {th }}$ November during the two seasons. Normal agricultural practices were used in the due time and no chemical control was applied.

To survey, relative densities and seasonal abundance of coccinellid species and their insect parasitoids, ten wheat tillers infested with aphids were collected and kept each in a polyethylene bag, and carefully transferred to the laboratory to be examined under a stereoscopic microscope. Adults and nymphs of aphid were counted. Coccinellid predators in most cases were directly counted and in few cases laboratory rearing was necessary for the immature stages up to adult emergence to be counted and identified. Eggs of coccinellid predators found on tillers wheat were collected, counted and isolated according to the color, (yellow, brown and black). The un-parasitized eggs, yellow ones, were put singly in plastic vials, $7 \times 2 \mathrm{~cm}$, and were observed daily until hatching. Newly hatched larvae were provided daily with aphids until pupation. The parasitized brown and black eggs were placed singly in plastic vials until parasitoids emergence. Some of the parasitoid adults were killed and kept in specimen vials containing $70 \%$ ethyl alcohol and glycerin. Larvae of coccinellid predators reared individually in Petri- dishes, $10 \mathrm{~cm}$ diameter, on $R$. aphids an $S$. graminum until pupation and emergence of the predators or parasitoids. The parasitoids were collected, counted and preserved in glass vials containing $70 \%$ ethyl alcohol and glycerin. The pupae were isolated, then placed individually in clean plastic vials and kept till the emergence of the predators or parasitoids. The parasitoids specimens were mounted in canada balsam on glass slides for identification. The parasitoids were identified in Biological Control Department, Plant Protection Research Institute, ARC, Giza, Egypt with the help of Prof. Dr. Ahmed R. Hamed, Chief of Biological Control Research. Daily records of temperatures and relative humidities during the period of investigation were obtained from Agrometeorological Station in Egypt. Simple correlation coefficient (r), simple regression coefficient (b) was calculated.

Statistical analysis of data was conducted using general linear model (GLM) and regression (Reg.) in SAS (SAS institute).

\section{RESULTS AND DISCUSSION}

\section{Survey and Relative Densities of Coccinellid Species Associated with Aphids Infesting Wheat Plants in Belbis District, Sharkia Governorate during 2015-2016 and 2016-2017 Seasons}

Results presented in Table 1 show that several Coccinellid species, belong to family Coccinellidae were surveyed associated with aphids infested wheat plants. The species could be arranged descendingly according to their 
Table 1. Survey and relative densities of Coccinellid species associated with aphids infesting wheat plants in Belbis District, Sharkia Governorate during 2015-2016 and 2016-2017 seasons

\begin{tabular}{|c|c|c|c|c|c|c|c|c|c|c|}
\hline \multirow[t]{3}{*}{ Family } & \multirow[t]{3}{*}{ Species } & \multicolumn{4}{|c|}{ Season } & \multirow{2}{*}{\multicolumn{2}{|c|}{ General }} & \multirow{2}{*}{\multicolumn{2}{|c|}{$\begin{array}{c}\text { Total ratio of } \\
\text { predator : prey }\end{array}$}} & \multirow{3}{*}{$\begin{array}{c}\text { General } \\
\text { ratio of } \\
\text { predator } \\
\text { prey } \\
\end{array}$} \\
\hline & & \multicolumn{2}{|c|}{ 2015-2016 } & \multicolumn{2}{|c|}{ 2016-2017 } & & & & & \\
\hline & & No. & $\begin{array}{r}\text { Dom. } \\
(\%)\end{array}$ & No. & $\begin{array}{c}\text { Dom. } \\
(\%)\end{array}$ & No. & $\begin{array}{c}\text { Dom. } \\
(\%)\end{array}$ & $\begin{array}{l}2015- \\
2016 \\
\end{array}$ & $\begin{array}{l}2016- \\
2017 \\
\end{array}$ & \\
\hline \multirow{7}{*}{ Coccinellidae } & C. undecimpunctata & 116 & 29.82 & 100 & 38.6 & 216 & 33.33 & $1: 18.41$ & $1: 16.34$ & $1: 17.45$ \\
\hline & C. septempunctata & 72 & 18.51 & 64 & 24.7 & 136 & 20.99 & $1: 29.67$ & $1: 25.53$ & $1: 27.72$ \\
\hline & C. 9-punctata & 69 & 17.74 & 57 & 22.0 & 126 & 19.44 & $1: 30.96$ & $1: 28.67$ & $1: 29.92$ \\
\hline & S. syriacus & 62 & 15.94 & 18 & 6.9 & 80 & 12.35 & $1: 34.45$ & $1: 90.8$ & 1:47.13 \\
\hline & S. interruptus & 37 & 9.51 & 11 & 4.3 & 48 & 7.41 & $1: 57.73$ & $1: 148.5$ & $1: 78.54$ \\
\hline & C. vicina isis & 20 & 5.14 & 6 & 2.3 & 26 & 4.01 & $1: 106.8$ & $1: 272.3$ & $1: 145$ \\
\hline & C.vicina nilotica & 13 & 3.34 & 3 & 1.2 & 16 & 2.47 & $1: 164.31$ & $1: 544.7$ & $1: 235.63$ \\
\hline General total & & 389 & 100 & 259 & 100 & 648 & 100 & $1: 5.49$ & 1:6.31 & $1: 5.81$ \\
\hline
\end{tabular}

Dom. $=$ Dominance

dominance persentages in the two seasons of study as follows: Coccinella undecimpunctata L., Coccinella septempunctata L., Coccinella 9-punctata L., Scymnus syriacus Mars, Scymnus interruptus (Goeze), Cydonia vicina isis $\mathrm{Cr}$. and Cydonia vicina nilotica Muls., with general dominance, 33.33, 20.99, 19.44, 12.35, $7.41,4.01$ and $2.47 \%$ of the total count of Coccinellid species, respectively.

According the predator: prey ratio, $C$. undecimpunctata recorded the highest ratio $(1: 18.41$ and $1: 16.34)$ in the two seasons with general ratio (1:17.45) and C.vicina nilotica had the lowest one (1:164.31 and 1:544.7) with general ratio (1:235.63), respectively. Total predator: prey ratio was 1:5.49 and 1:6.31 in the 2015/2016 and 2016/2017 seasons, respectively with general ratio of 1:5.81.

The presented results are in agreement with the findings of Vandereycken et al. (2015) who surveyed seven aphidophagous ladybirds viz., C. undecimpunctata, C. septempunctata, Coccinella quinquepunctata L., Harmonia axyridis Pallas, Hippodamia undecimnotata Schneider, H. variegate Goeze and Propylea quatuordecimpunctata L. on aphids, infesting wheat plants.
Also Ahmed et al. (2016) found that Coccinella sp. was recorded associated with aphids on wheat plants.

Youssif et al. (2017) in Egypt, recorded six preadaceous insect species belonging to four orders and five families associated with aphid species infesting wheat plants.

Among all recorded preadaceous species, $C$. undecimpunctata and $C$. septempunctata were the most dominant species, comprised 15.68 and $15.26 \%$ of the total count of the predators, respectively.

Youssif (2019) in Egypt recorded seven species of Coccinellid predators on aphids infesting pear trees.

\section{Seasonal Abundance of Coccinellid Species \\ C. undecimpunctata}

Results given in Table 2 reveal that in the first season, the first record of $C$. undecimpunctata at $4^{\text {th }}$ week of 30 individuals. Three weeks late after the first appearance of the aphids, 386 individuals/sample, at means of $19.5^{\circ} \mathrm{C}$ and $51.0 \% \mathrm{RH}$. The predator population showed a distinct peak of 33 individuals/304 aphids in the $1^{\text {st }}$ week of March at means of $22.4^{\circ} \mathrm{C}$ and $49.5 \% \mathrm{RH}$. 
Table 2. Seasonal abundance of Coccinellid species associated with aphid infesting wheat plants in Belbis District, Sharkia Governorate during 2015 - 2016 season

\begin{tabular}{|c|c|c|c|c|c|c|c|c|c|c|c|c|}
\hline \multirow[t]{2}{*}{$\begin{array}{l}\text { Weekly date } \\
\text { of sample }\end{array}$} & \multirow{2}{*}{$\begin{array}{c}\text { Number of } \\
\text { aphid } \\
\text { (10 samples) }\end{array}$} & \multicolumn{8}{|c|}{ Number of coccinellid species } & \multirow[t]{2}{*}{$\begin{array}{l}\text { Predators } \\
\text { : prey }\end{array}$} & \multicolumn{2}{|c|}{$\begin{array}{c}\text { Corresponding } \\
\text { means of }\end{array}$} \\
\hline & & 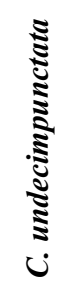 & 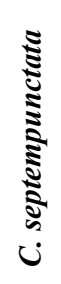 & 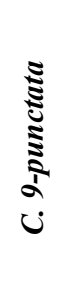 & 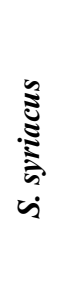 & 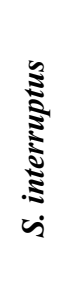 & 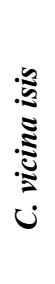 & 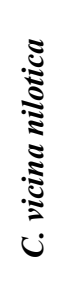 & 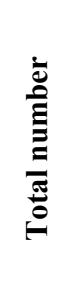 & & $\underset{{ }^{\circ} \mathrm{C}}{\text { Temp. }}$ & $\begin{array}{l}\text { RH } \\
(\%)\end{array}$ \\
\hline Feb., $1^{\text {st }}(2016)$ & 44 & 0 & 0 & 0 & 0 & 0 & 0 & 0 & 0 & $0: 44.0$ & 13.0 & 67.5 \\
\hline $2^{\text {nd }}$ & 135 & 0 & 0 & 0 & 0 & 0 & 0 & 0 & 0 & $0: 135.0$ & 14.9 & 57.2 \\
\hline $3^{\text {rd }}$ & 240 & 0 & 0 & 0 & 0 & 0 & 0 & 0 & 0 & $0: 240.0$ & 20.3 & 46.4 \\
\hline $4^{\text {th }}$ & 386 & 30 & 10 & 15 & 18 & 10 & 1 & 2 & 86 & $1: 4.49$ & 19.5 & 51.0 \\
\hline Total & 805 & 30 & 10 & 15 & 18 & 10 & 1 & 2 & 86 & $1: 9.36$ & & \\
\hline Mar., $1^{\text {st }}$ & 304 & 33 & 29 & 20 & 15 & 10 & 9 & 5 & 121 & $1: 2.51$ & 22.4 & 49.5 \\
\hline $2^{\text {nd }}$ & 285 & 23 & 15 & 13 & 12 & 7 & 2 & 1 & 73 & $1: 3.90$ & 20.5 & 48.7 \\
\hline $3^{\text {rd }}$ & 250 & 15 & 13 & 10 & 10 & 5 & 2 & 3 & 58 & $1: 4.31$ & 21.8 & 43.0 \\
\hline $4^{\text {th }}$ & 192 & 8 & 2 & 7 & 3 & 3 & 4 & 1 & 28 & $1: 6.86$ & 20.0 & 47.7 \\
\hline $5^{\text {th }}$ & 145 & 4 & 1 & 2 & 2 & 1 & 1 & 1 & 12 & 1:12.08 & 21.6 & 43.8 \\
\hline Total & 1176 & 83 & 60 & 52 & 42 & 26 & 18 & 11 & 292 & $1: 4.03$ & & \\
\hline Apr., $1^{\text {st }}$ & 110 & 2 & 1 & 1 & 1 & 1 & 1 & 0 & 7 & $1: 15.71$ & 22.7 & 53.7 \\
\hline $2^{\text {nd }}$ & 45 & 1 & 1 & 1 & 1 & 0 & 0 & 0 & 4 & $1: 11.25$ & 26.4 & 40.7 \\
\hline Total & 155 & 3 & 2 & 2 & 2 & 1 & 1 & $\mathbf{0}$ & 11 & 1:14.09 & & \\
\hline General total & 2136 & 116 & 72 & 69 & 62 & 37 & 20 & 13 & 389 & & & \\
\hline
\end{tabular}

The highest total monthly numbers of C. undecimpunctata was 83 ladybeetle/1176 aphids, that was found during March, while and the lowest count, three predators $/ 155$ aphids was recorded during April.

As shown from the obtained results in Table 3 , in the second season, the predator occurred from the $3^{\text {rd }}$ week of February till the $2^{\text {nd }}$ week of April. During this period, the predator population showed two peaks of activity. The first one, 14 ladybeetle/214 aphids, took place in the $4^{\text {th }}$ week of February at means of $18.5^{\circ} \mathrm{C}$ and $59.3 \% \mathrm{RH}$. The second and the highest peak with 22 ladybeetle/237 aphids occurred in the $3^{\text {rd }}$ week of March at means of $19.2^{\circ} \mathrm{C}$ and $62.1 \% \mathrm{RH}$.

The predator population showed the highest total monthly of 77 ladybeetles/1053 aphids during March, while only two ladybeetles /69 aphids was recorded during April.

Mohamed et al. (2000) found that the most consistently abundant predators associated with the Russion wheat aphid D. noxia was the Coccinellid species. Abd El-Megid et al. (2007) stated that the maximum monthly total count of C. undecimpunctata was recorded during April. Mean while, the lowest value, one individual, was obtained during February. The mean of predator: prey ratio during the season was 1: 30.77. Youssif et al. (2017) added that the population of $C$. undecimpunctata was detected from the $4^{\text {th }}$ week of January till the $4^{\text {th }}$ week of April. Generally the predator population was fluctuated, showing three peaks in $3^{\text {rd }}$ week of February, $1^{\text {st }}$ week of March and $2^{\text {nd }}$ week of April. 
Table 3. Seasonal abundance of Coccinellid species associated with aphid infesting wheat plants in Belbis District, Sharkia Governorate during 2016 - 2017 season

\begin{tabular}{|c|c|c|c|c|c|c|c|c|c|c|c|c|}
\hline \multirow[t]{2}{*}{$\begin{array}{c}\text { Weekly date of } \\
\text { sample }\end{array}$} & \multirow{2}{*}{$\begin{array}{c}\text { Number of } \\
\text { aphid } \\
\text { (10 samples) }\end{array}$} & \multicolumn{8}{|c|}{ Number of coccinellid species } & \multirow[t]{2}{*}{$\begin{array}{l}\text { Predators } \\
\text { : prey }\end{array}$} & \multicolumn{2}{|c|}{$\begin{array}{l}\text { Corresponding } \\
\text { means of }\end{array}$} \\
\hline & & 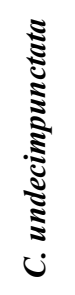 & 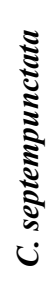 & 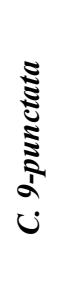 & 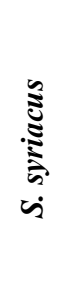 & 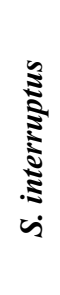 & 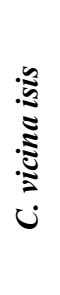 & 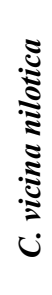 & 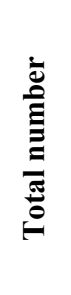 & & $\begin{array}{c}\text { Temp. } \\
{ }^{\circ} \mathrm{C}\end{array}$ & $\begin{array}{l}\text { RH } \\
(\%)\end{array}$ \\
\hline$\overline{\text { Feb., } 1^{\text {st }}(2017)}$ & 32 & 0 & 0 & 0 & 0 & 0 & 0 & 0 & 0 & $0: 32.0$ & 18.5 & 59.3 \\
\hline $2^{\text {nd }}$ & 81 & 0 & 0 & 0 & 0 & 0 & 0 & 0 & 0 & $0: 81.0$ & 15.3 & 63.3 \\
\hline $3^{\text {rd }}$ & 185 & 7 & 3 & 2 & 1 & 1 & 0 & 0 & 14 & $0: 13.21$ & 16.3 & 63.7 \\
\hline $4^{\text {th }}$ & 214 & 14 & 10 & 5 & 2 & 1 & 1 & 0 & 33 & $0: 6.48$ & 18.5 & 59.3 \\
\hline Total & 512 & 21 & 13 & 7 & 3 & 2 & 1 & $\mathbf{0}$ & 47 & 0:10.89 & & \\
\hline Mar., $1^{\text {st }}$ & 289 & 12 & 3 & 9 & 1 & 1 & 1 & 1 & 28 & 1:13.14 & 21.3 & 58.2 \\
\hline $2^{\text {nd }}$ & 265 & 18 & 8 & 10 & 0 & 2 & 1 & 1 & 40 & $1: 8.28$ & 19.9 & 63.3 \\
\hline $3^{\text {rd }}$ & 237 & 22 & 22 & 14 & 5 & 2 & 1 & 1 & 67 & $1: 3.25$ & 19.2 & 62.1 \\
\hline $4^{\text {th }}$ & 164 & 18 & 12 & 5 & 7 & 3 & 1 & 0 & 46 & $1: 3.28$ & 18.3 & 60.3 \\
\hline $5^{\text {th }}$ & 98 & 7 & 5 & 12 & 0 & 1 & 1 & 0 & 26 & $1: 3.27$ & 19.3 & 62.0 \\
\hline Total & 1053 & 77 & 50 & 50 & 13 & 9 & 5 & 3 & 207 & $1: 5.09$ & & \\
\hline Apr., $1^{\text {st }}$ & 54 & 1 & 1 & 0 & 1 & 0 & 0 & 0 & 3 & 1:18.00 & 20.3 & 59.2 \\
\hline $2^{\text {nd }}$ & 15 & 1 & 0 & 0 & 1 & 0 & 0 & 0 & 2 & $1: 7.5$ & 20.0 & 53.9 \\
\hline Total & 69 & 2 & 1 & $\mathbf{0}$ & 2 & $\mathbf{0}$ & $\mathbf{0}$ & $\mathbf{0}$ & 5 & 1:13.8 & & \\
\hline General total & 1634 & 100 & 64 & 57 & 18 & 11 & 6 & 3 & 259 & & & \\
\hline
\end{tabular}

\section{C. septempunctata}

In the first season, results given in Table 2 indicate that the predator was detected from the $4^{\text {th }}$ week of February till the $2^{\text {nd }}$ week of April. During this period, $C$. septempunctata population showed one peak, 29 ladybeetles/ 304 aphids in the $1^{\text {st }}$ week of March at means of $22.4^{\circ} \mathrm{C}$ and $49.5 \% \mathrm{RH}$. The maximum monthly total number, 60 ladybeetles/1176 aphids, occurred during March and the lowest one, two ladybeetles/155 aphids was recorded during April. The predator:prey ratio during the first season, results obtained in Table 1 was $1: 29.67$. In the second season results obtained in Table 3 reveal that the first record of the predator, three individuals/ sample, started two weeks late after the first appearance of the aphids, 185 individuals/ sample, in the $3^{\text {rd }}$ week of February at means of $16.3^{\circ} \mathrm{C}$ and $63.7 \%$ RH. Then, the predator population was increased to reach its highest peak of 22 ladybeetles in the $3^{\text {rd }}$ week of March at means of $19.2^{\circ} \mathrm{C}$ and $62.1 \%$ RH. The maximum total monthly numbers, 50 ladybeetles/ 1053 aphids, occurred during March and the lowest one recorded one ladybeetles/69 aphids, were obtained during April. The mean ratio of predator: aphids during the season was 1:25.53.

Sajioqi et al. (2009) recorded the highest number of $C$. septempunctata during the $3^{\text {rd }}$ week of March. The population of the predator started decline with the decrease in aphid population and in the last week of April the lowest population of the predator was recorded. Youssif et al. (2017) stated that the predator was detected through the period from the $1^{\text {st }}$ 
week of January to the $2^{\text {nd }}$ week of April, showed two peaks of activity, the first one of 12 predators was in the $2^{\text {nd }}$ week of February. The second and highest peak of 15 predators took place in the $1^{\text {st }}$ week of March.

\section{9-punctata}

As shown from the obtained results in Table 2 , the first appearance of the predator in the first season with 15 ladybeetles/386 aphids was in the $4^{\text {th }}$ week of February, three week late after the first record of the aphids. Thereafter, the predator was recorded in all samples recorded one peak of 20 ladybeetles/304 aphids in the $1^{\text {st }}$ week of March at means of $22.4^{\circ} \mathrm{C}$ and $49.5 \% \mathrm{RH}$. Thereafter, the predator number was decreased gradually. The maximum total monthly number, 52 ladybeetles/1176 aphids, was obtained during March, while only two ladybeetles /155 aphids was recorded during April. Results given in Table 3 reveal that in the second season C. 9-punctata occurred from the $3^{\text {rd }}$ week of February till the $5^{\text {th }}$ week of March. During this period, the predator population showed two peaks of activity. The first one, 14 ladybeetles/237 aphids, took place in the $3^{\text {rd }}$ week of March at means of $19.2^{\circ} \mathrm{C}$ and $62.1 \% \mathrm{RH}$. The second peak with 12 ladybeetles/98 aphids, occurred in the $5^{\text {th }}$ week of March at means of $19.3^{\circ} \mathrm{C}$ and $62.0 \% \mathrm{RH}$. The mean ratio of predator to aphid was not detected during April. The highest total monthly number, 50 ladybeetles/1053 aphids was recorded during March, and the lowest one, seven ladybeetles/512 aphids was obtained during February.

James et al. (2012) reported that the highest number of C. 9-punctata was recorded in April and May in open field infesting with aphids.

\section{Seasonal abundance of the total number of Coccinellid species}

In the first season, the results presented in Table 2 reveal that the Coccinellidae predators were detected from the $4^{\text {th }}$ week of February till the $2^{\text {nd }}$ week of April, with the exception of the $1^{\text {st }}$, 2nd and $3^{\text {rd }}$ week of February. The total number of Coccinellid species showed one peak of activity, 121 predators/ 304 aphids was observed in the $1^{\text {st }}$ week of March at means of $22.4^{\circ} \mathrm{C}$ and $49.5 \% \mathrm{RH}$. Thereafter, the total number of predators decreased gradually to record its minimum value, four individuals/45 aphids in the $2^{\text {nd }}$ week of April at means of $26.4^{\circ} \mathrm{C}$ and $40.7 \%$ RH. The highest total monthly number of 292 predators/1176 aphids was recorded during March, while the lowest value, 11 predators/155 aphids was noticed during April. The mean of predator: prey ratio during the whole season was 1:5.49.

In the second season, the results obtained in Table 3 reveal that the Coccinellid species was detected during the period from the $3^{\text {rd }}$ week of February till the $2^{\text {nd }}$ week of April. The total number of predators appeared two peaks during the season. The first and lowest peak, 33 ladybeetles $/ 214$ aphids, occurred in the $4^{\text {th }}$ week of February at means of $18.5^{\circ} \mathrm{C}$ and $59.3 \% \mathrm{RH}$. The second and the highest peak with the total number of 67 ladybeetles /237 aphids, took place in the $3^{\text {rd }}$ week of March at means of $19.2^{\circ} \mathrm{C}$ and $62.1 \% \mathrm{RH}$. The maximum total monthly number of 207 ladybeetles/1053 aphids, was obtained during March, while the minimum one, five ladybeetles/69 aphids was noticed during April. The predator : prey ratio during the season was 1:6.31.

Statistical analysis indicated that there were positive correlations and highly significant between aphids and predators count during the two successive seasons, whereas (r) values were $0.814^{* *}$ and $0.748^{* *}$ during the first and second seasons, respectively.

Youssif et al. (2017) in Egypt indicated that the initial aphids infestation was recorded in the $2^{\text {nd }}$ week of January, while the first record of the Coccinellid species two individuals was in the $2^{\text {nd }}$ week of January, the population of predators fluctuated showed three peaks. The total recorded predators showed that means of $1: 61.62$ and $1: 118.73$ predators : prey ratios in the first and second seasons, respectively.

\section{Survey and relative densities of Coccinellid parasitoids}

Results given in Table 4 reveal that five species of hymenopterous parasitoids belong to three families were recorded. One egg parasitoid species, (Telenomus sp., Scelionidae.) was emerged from collected eggs of Coccinellid 
Zagazig J. Agric. Res., Vol. 47 No. (4) 2020

Table 4. Survey and relative densities of parasitoids emerged from different immature stages of Coccinellid associated with aphid infesting wheat plants in Belbis District, Sharkia Governorate during 2015-2016 and 2016-2017 seasons

\begin{tabular}{|c|c|c|c|c|c|c|c|c|c|c|}
\hline \multirow[t]{2}{*}{ Specie } & \multirow[t]{2}{*}{ Family } & \multicolumn{3}{|c|}{ 2015-2016 } & \multicolumn{3}{|c|}{ 2016-2017 } & \multicolumn{3}{|c|}{ General } \\
\hline & & $\begin{array}{c}\text { No. } \\
\text { (parasitoid/ } \\
\text { predator) }\end{array}$ & $\begin{array}{c}\text { Total } \\
\text { parasitism } \\
(\%) \\
\end{array}$ & $\begin{array}{l}\text { Dom. } \\
\text { (\%) }\end{array}$ & $\begin{array}{c}\text { No. } \\
\text { (parasitoid/ } \\
\text { predator) }\end{array}$ & $\begin{array}{c}\text { Total } \\
\text { parasitism } \\
(\%) \\
\end{array}$ & $\begin{array}{l}\text { Dom. } \\
\text { (\%) }\end{array}$ & $\begin{array}{c}\text { No. } \\
\text { (parasitoid/ } \\
\text { predator) }\end{array}$ & $\begin{array}{l}\text { Parasitism } \\
\text { (\%) }\end{array}$ & $\begin{array}{l}\text { Dom. } \\
(\%)\end{array}$ \\
\hline \multicolumn{11}{|l|}{ Eggs parasitoid, } \\
\hline Telenomus sp. & Scelionidae & $32 / 301$ & 10.63 & 56.14 & $17 / 209$ & 8.13 & 68 & $49 / 510$ & 9.61 & 59.8 \\
\hline \multicolumn{11}{|l|}{ Larval parasitoid, } \\
\hline Perilitus coccinellae (Schrank) & Braconidae & $9 / 54$ & 16.67 & 15.79 & $3 / 25$ & 12.00 & 12 & $12 / 79$ & 15.19 & 14.6 \\
\hline \multicolumn{11}{|l|}{ Pupal parasitoids, } \\
\hline Tetrastichus coccinellae Kurd & Eulophidae & $9 / 34$ & 26.47 & 15.79 & $2 / 25$ & 8.00 & 8 & $11 / 59$ & 18.64 & 13.4 \\
\hline Tetrastichus principae Domenichini & Eulophidae & $5 / 34$ & 14.71 & 8.77 & $2 / 25$ & 8.00 & 8 & $7 / 59$ & 11.86 & 8.5 \\
\hline Tetrastichus sp. & Eulophidae & $2 / 34$ & 5.88 & 3.51 & $1 / 25$ & 4.00 & 4 & $3 / 59$ & 5.08 & 3.7 \\
\hline General total & & $57 / 389$ & 14.65 & 100 & $25 / 259$ & 9.65 & 100 & $82 / 648$ & 12.65 & 100 \\
\hline
\end{tabular}

species. One larval parasitoid (Perilitus coccinellae (Schrank), Braconidae) and three pupal parasitoids namely Tetrastichu coccinellae Kurd, Tetrastichus principiae Domenichini and Tetrastichus sp. belong to family Eulophidae were emerged from collected Coccinellid species.

In the first season the pupal parasitoid, T. coccinellae came in the first rank, represented by total parasitism percentage of $26.47 \%$ and in the second one larval parasitoid $T$. principiae had the highest percentage, $12 \%$. Concerning the general parasitism percentage during the two seasons, the pupal parasitoid, T. coccinellae recorded the highest persenteg, $18.64 \%$.

The general total parasitism percentages of coccinellid species were 14.66 and $9.65 \%$ in the first and second seasons, consecutively.

The parasitoids could be arranged descendingly according to their general dominance percentages during the two seasons of study as follow:

Telenomus sp., P. coccinellae, T. coccinellae, T. principiae and Tetrastichus sp. by 59.8, 14.6, $13.4,8.5$ and $3.7 \%$ of the total collected parasitoids, respectively.
The present results are in agreement with those of Keiko et al. (1995) who mentioned that $P$. coccinellae is a parasitoid of $C$. septempunctata on pear trees infesting with aphids. Youssif (2019) in Egypt, recorded five species of hymenopterous parasitoids attack egg parasitoid Telenomus, larvae parasitoid Perilitus coccinellae and pupae parasitoid Tetrastichus coccinellae, Tetrastichus principae of Coccinellid species.

\section{Seasonal Abundance of Coccinellid Parasitoids}

\section{Egg parasitoid, Telenomus sp.}

Results presented in Table 5 indicate that in the first season, the endo parasitoid, Telenomus sp. parasitized Coccinellid eggs during the period extended from the $2^{\text {nd }}$ week of March till the $2^{\text {nd }}$ week of April. The parasitism percentages indicated two peaks. The first peak, $14.52 \%$ was recorded in the $2^{\text {nd }}$ week of March at means of $20.5^{\circ} \mathrm{C}$ and $48.7 \% \mathrm{RH}$. The second one of $71.43 \%$, took place in the $4^{\text {th }}$ week of March at means of $21.6^{\circ} \mathrm{C}$ and $43.8 \% \mathrm{RH}$. The maximal and minimal monthly means of parasitism percentages were detected during March and April, with 16.67 and 13.03\%, respectively. In the second season, Telenomus sp. 
Table 5. Seasonal abundance of egg Coccinellid parasitoid, Telenomus sp. and parasitism percentages on Coccinellid Species associated with aphid infesting wheat plants in Belbis District, Sharkia Governorate during 2015-2016 and 2016- 2017 seasons

\begin{tabular}{|c|c|c|c|c|c|c|c|c|c|c|}
\hline \multirow{3}{*}{$\begin{array}{c}\text { Weekly date } \\
\text { of sample }\end{array}$} & \multicolumn{4}{|c|}{ Number of } & \multirow{2}{*}{\multicolumn{2}{|c|}{$\begin{array}{c}\text { Egg } \\
\text { parasitism (\%) }\end{array}$}} & \multicolumn{4}{|c|}{ Corresponding means of } \\
\hline & \multicolumn{2}{|c|}{ Collected eggs } & \multicolumn{2}{|c|}{$\begin{array}{c}\text { Emerged } \\
\text { parasitoids }\end{array}$} & & & \multicolumn{2}{|c|}{ Temp. $\left({ }^{\circ} \mathrm{C}\right)$} & \multicolumn{2}{|c|}{ RH (\%) } \\
\hline & 2016 & 2017 & 2016 & 2017 & 2016 & 2017 & 2016 & 2017 & 2016 & 2017 \\
\hline Feb., $1^{\text {st }}$ & 0 & 0 & 0 & 0 & 0.00 & 0.00 & 13.0 & 18.5 & 67.5 & 59.3 \\
\hline $2^{\text {nd }}$ & 0 & 0 & 0 & 0 & 0.00 & 0.00 & 14.9 & 15.3 & 57.2 & 63.3 \\
\hline $3^{\text {rd }}$ & 0 & 10 & 0 & 0 & 0.00 & 0.00 & 20.3 & 16.3 & 46.4 & 63.7 \\
\hline $4^{\text {th }}$ & 57 & 23 & 0 & 1 & 0.00 & 4.35 & 19.5 & 18.5 & 51.0 & 59.3 \\
\hline Total & 57 & 33 & $\mathbf{0}$ & 1 & 0.00 & 3.03 & & & & \\
\hline Mar., $\mathbf{1}^{\text {st }}$ & 93 & 15 & 0 & 1 & 0.00 & 6.67 & 22.4 & 21.3 & 49.5 & 58.2 \\
\hline $2^{\text {nd }}$ & 62 & 28 & 9 & 0 & 14.52 & 0.00 & 20.5 & 19.9 & 48.7 & 63.3 \\
\hline $3^{\text {rd }}$ & 53 & 65 & 5 & 1 & 9.43 & 1.54 & 21.8 & 19.2 & 43.0 & 62.1 \\
\hline $4^{\text {th }}$ & 23 & 43 & 12 & 8 & 52.17 & 18.60 & 20.0 & 18.3 & 47.7 & 60.3 \\
\hline $5^{\text {th }}$ & 7 & 22 & 5 & 5 & 71.43 & 22.73 & 21.6 & 19.3 & 43.8 & 62.0 \\
\hline Total & 238 & 173 & 31 & 15 & 13.03 & 8.67 & & & & \\
\hline Apr., $1^{\text {st }}$ & 4 & 2 & 1 & 1 & 25 & 50 & 22.7 & 20.3 & 53.7 & 59.2 \\
\hline $2^{\text {nd }}$ & 2 & 1 & 0 & 0 & 0.00 & 0.00 & 26.4 & 20.0 & 40.7 & 53.9 \\
\hline Total & 6 & 3 & 1 & 1 & 16.67 & 33.33 & & & & \\
\hline General total & 301 & 209 & 32 & 17 & 10.63 & 8.13 & & & & \\
\hline
\end{tabular}

parasitized Coccinellid eggs during the period from $4^{\text {th }}$ week of February till the first week of April except in the $2^{\text {nd }}$ week of March.

The parasitoid indicated two peaks, the first and lowest one, of $6.67 \%$ parasitism was obtained in the $4^{\text {th }}$ week of February at means of $22.4^{\circ} \mathrm{C}$ and $49.5 \% \mathrm{RH}$. The second and highest one, $22.73 \%$ parasitism took place in the $5^{\text {th }}$ week of March at means of $19.3^{\circ} \mathrm{C}$ and $62.0 \%$ RH. The highest and lowest monthly means of parasitism percentages were found during March and February with 8.67 and $3.03 \%$, respectively. In general, Telenomus sp. showed general total of 10.63 and $8.13 \%$ parasitism in the first and second seasons, respectively.
Youssif (2019) stated that the Telenomus sp. in an egg parasitoids parasitized Coccinellid eggs.

\section{Larval parasitoid, $P$. coccinellae}

$P$. coccinellae was recorded as solitary endo larval parasitoid attack Coccinellid larvae, then, the parasitoid emerged from the $4^{\text {th }}$ larval instar of predator. As shown in Table 6 in the first season, $P$. coccinellae occurred from the $4^{\text {th }}$ week of March till the $1^{\text {st }}$ week of April. During this period, the parasitism percentages showed one peak, $40.0 \%$, took place in the $4^{\text {th }}$ week of March at means of $20.0^{\circ} \mathrm{C}$ and $47.7 \% \mathrm{RH}$. No individuals of this parasitoid were detected during February. The highest monthly mean of parasitism percentages $21.21 \%$ was recorded 
Table 6. Seasonal abundance of larval Coccinellid parasitoid, $P$. coccinellae and parasitism percentages on Coccinellid Species associated with aphid infesting wheat plants in Belbis District, Sharkia Governorate during 2015-2016 and 2016- 2017 seasons

\begin{tabular}{|c|c|c|c|c|c|c|c|c|c|c|}
\hline \multirow{3}{*}{$\begin{array}{c}\text { Weekly date of } \\
\text { sample }\end{array}$} & \multicolumn{4}{|c|}{ Number of } & \multirow{2}{*}{\multicolumn{2}{|c|}{$\begin{array}{c}\text { Larval } \\
\text { parasitism (\%) }\end{array}$}} & \multicolumn{4}{|c|}{ Corresponding means of } \\
\hline & \multicolumn{2}{|c|}{$\begin{array}{l}\text { Collected } \\
\text { larvae }\end{array}$} & \multicolumn{2}{|c|}{$\begin{array}{l}\text { Emerged } \\
\text { parasitoid }\end{array}$} & & & \multicolumn{2}{|c|}{ Temp. $\left({ }^{\circ} \mathrm{C}\right)$} & \multicolumn{2}{|c|}{ RH (\%) } \\
\hline & 2016 & 2017 & 2016 & 2017 & 2016 & 2017 & 2016 & 2017 & 2016 & 2017 \\
\hline Feb., $1^{\text {st }}$ & 0 & 0 & 0 & 0 & 0.00 & 0.00 & 13.0 & 18.5 & 67.5 & 59.3 \\
\hline $2^{\text {nd }}$ & 0 & 0 & 0 & 0 & 0.00 & 0.00 & 14.9 & 15.3 & 57.2 & 63.3 \\
\hline $3^{\text {rd }}$ & 0 & 0 & 0 & 0 & 0.00 & 0.00 & 20.3 & 16.3 & 46.4 & 63.7 \\
\hline $4^{\text {th }}$ & 0 & 0 & 0 & 0 & 0.00 & 0.00 & 19.5 & 18.5 & 51.0 & 59.3 \\
\hline Total & $\mathbf{0}$ & $\mathbf{0}$ & $\mathbf{0}$ & $\mathbf{0}$ & 0.00 & 0.00 & & & & \\
\hline Mar., $1^{\text {st }}$ & 0 & 0 & 0 & 0 & 0.00 & 0.00 & 22.4 & 21.3 & 49.5 & 58.2 \\
\hline $2^{\text {nd }}$ & 1 & 0 & 0 & 0 & 0.00 & 0.00 & 20.5 & 19.9 & 48.7 & 63.3 \\
\hline $3^{\text {rd }}$ & 11 & 0 & 0 & 0 & 0.00 & 0.00 & 21.8 & 19.2 & 43.0 & 62.1 \\
\hline $4^{\text {th }}$ & 5 & 2 & 2 & 1 & 40.0 & 50.0 & 20.0 & 18.3 & 47.7 & 60.3 \\
\hline $5^{\text {th }}$ & 16 & 8 & 5 & 1 & 31.25 & 12.5 & 21.6 & 19.3 & 43.8 & 62.0 \\
\hline Total & 33 & 10 & 7 & 2 & 21.21 & 20.0 & & & & \\
\hline Apr., $1^{\text {st }}$ & 13 & 10 & 2 & 1 & 15.38 & 10 & 22.7 & 20.3 & 53.7 & 59.2 \\
\hline $2^{\text {nd }}$ & 8 & 5 & 0 & 0 & 0.00 & 0.00 & 26.4 & 20.0 & 40.7 & 53.9 \\
\hline Total & 21 & 15 & 2 & 1 & 9.52 & 6.67 & & & & \\
\hline General total & 54 & 25 & 9 & 3 & 16.67 & 12.00 & & & & \\
\hline
\end{tabular}

during March, while the lowest value, $9.52 \%$ was found during April. Similar trend was obtained in the second season, where as the parasitoid was found from the $4^{\text {th }}$ week of March to the $1^{\text {st }}$ week of April. The parasitoid showed one peak, $50.0 \%$, was obtained in the $4^{\text {th }}$ week of March at means of $18.3^{\circ} \mathrm{C}$ and $60.3 \% \mathrm{RH}$. Number of parasitism could be detected during February. The highest monthly mean of parasitism percentages $20.0 \%$, was recorded during March, while the lowest value, $6.67 \%$ was found during April. Generally, larval parasitoid $P$. coccinellae indicated general tatal percentages of 16.67 and $12.00 \%$ parasitism in the first and second seasons, respectively.

Keiko et al. (1995) mentioned that $P$. coccinellae is a parasitoid of C. septempunctata. Richerson and Deloech (2017) reported that the parasitoid
P. coccinellae attack Coccinella sp. associated with aphids infesting vegetable crops.

\section{Pupal parasitoid, T. principae}

Results presented in Table 7 show the fluctuations of pupal parasitoid, $T$. principiae on Coccinellid spesies associated with aphids infested wheat plants and parasitism (\%) during the two seasons of study.

In the first season, the parasitism percentages showed three peaks. The first one, 33.33\% parasitism occurred in the $3^{\text {rd }}$ week of March at means of $20.5^{\circ} \mathrm{C}$ and $48.7 \% \mathrm{RH}$. The second one, $28.57 \%$ took place in the $5^{\text {th }}$ week of March at means of $21.6^{\circ} \mathrm{C}$ and $43.8 \% \mathrm{RH}$. The third and highest peak, $50.0 \%$ was recorded in the $1^{\text {st }}$ week of April at means of $22.7^{\circ} \mathrm{C}$ and $53.7 \%$ RH. Number of pupal parasitoid was detected 
Table 7. Seasonal abundance of pupal Coccinellid parasitoid, T. principae and parasitism percentages on Coccinellid Species associated with aphid infesting wheat plants in Belbis District, Sharkia Governorate during 2015-2016 and 2016- 2017 seasons.

\begin{tabular}{|c|c|c|c|c|c|c|c|c|c|c|}
\hline \multirow{3}{*}{$\begin{array}{c}\text { Weekly date of } \\
\text { sample }\end{array}$} & \multicolumn{4}{|c|}{ Number of } & \multirow{2}{*}{\multicolumn{2}{|c|}{$\begin{array}{c}\text { Pupal } \\
\text { parasitism (\%) }\end{array}$}} & \multicolumn{4}{|c|}{ Corresponding means of } \\
\hline & \multicolumn{2}{|c|}{$\begin{array}{l}\text { Collected } \\
\text { pupa }\end{array}$} & \multicolumn{2}{|c|}{$\begin{array}{l}\text { Emerged } \\
\text { parasitoid }\end{array}$} & & & \multicolumn{2}{|c|}{ Temp. $\left({ }^{\circ} \mathrm{C}\right)$} & \multicolumn{2}{|c|}{ RH (\%) } \\
\hline & 2016 & 2017 & 2016 & 2017 & 2016 & 2017 & 2016 & 2017 & 2016 & 2017 \\
\hline Feb., $1^{\text {st }}$ & 0 & 0 & 0 & 0 & 0.00 & 0.00 & 13.0 & 18.5 & 67.5 & 59.3 \\
\hline $2^{\text {nd }}$ & 0 & 0 & 0 & 0 & 0.00 & 0.00 & 14.9 & 15.3 & 57.2 & 63.3 \\
\hline $3^{\text {rd }}$ & 1 & 0 & 0 & 0 & 0.00 & 0.00 & 20.3 & 16.3 & 46.4 & 63.7 \\
\hline $4^{\text {th }}$ & 0 & 4 & 0 & 1 & 0.00 & 25.0 & 19.5 & 18.5 & 51.0 & 59.3 \\
\hline Total & 1 & 4 & $\mathbf{0}$ & 1 & 0.00 & 25.0 & & & & \\
\hline Mar., $1^{\text {st }}$ & 3 & 5 & 0 & 0 & 0.00 & 0.00 & 22.4 & 21.3 & 49.5 & 58.2 \\
\hline $2^{\text {nd }}$ & 3 & 5 & 1 & 0 & 33.3 & 0.00 & 20.5 & 19.9 & 48.7 & 63.3 \\
\hline $3^{\text {rd }}$ & 9 & 2 & 3 & 1 & 33.3 & 50.0 & 21.8 & 19.2 & 43.0 & 62.1 \\
\hline $4^{\text {th }}$ & 9 & 4 & 2 & 0 & 22.22 & 0.00 & 20.0 & 18.3 & 47.7 & 60.3 \\
\hline $5^{\text {th }}$ & 7 & 4 & 2 & 0 & 28.57 & 0.00 & 21.6 & 19.3 & 43.8 & 62.0 \\
\hline Total & 31 & 20 & 8 & 1 & 25.81 & 5.0 & & & & \\
\hline Apr., $1^{\text {st }}$ & 2 & 0 & 1 & 0 & 50.0 & 0.00 & 22.7 & 20.3 & 53.7 & 59.2 \\
\hline $2^{\text {nd }}$ & 0 & 1 & 0 & 0 & 0.00 & 0.00 & 26.4 & 20.0 & 40.7 & 53.9 \\
\hline Total & 2 & 1 & 1 & $\mathbf{0}$ & 50.0 & 0.00 & & & & \\
\hline General total & 34 & 25 & 9 & 2 & 26.47 & 8.00 & & & & \\
\hline
\end{tabular}

during February. The maximum and minmum monthly means of parasitism percentages, 50.0 and 25.81\%, occurred in April and March, respectively.

In the second season, the results given in Table 7 show that the parasitism by pupal parasitoid indicated two peaks. The first peak, $25.0 \%$ was recorded in the $4^{\text {th }}$ week of February at means of $18.5^{\circ} \mathrm{C}$ and $59.3 \% \mathrm{RH}$. The second and the highest one, $50.0 \%$ took place in the $3^{\text {rd }}$ week of March at means of $19.2^{\circ} \mathrm{C}$ and $62.1 \% \mathrm{RH}$. Number of pupal parasitoid was detected during April. The highest and lowest monthly means of parasitism percentages, 50.0 and $25.0 \%$ were recorded during March and February, respectively. The general total percentages of parasitism by pupal parasitoids were 26.47 and $8.00 \%$ in the first and second seasons, respectively.
Gautam (1994) reported that the grubs and pupae of $C$. septempunctata were found parasitized by an eulophid $T$. coccinellae in vegetable crops infesting with aphids. El-Gepaly et al. (2018) added that $T$. coccinellae was the most dominant parasitoid reared from pupae of C. undecinmpunctata associated with aphid. Also, the $T$. coccinellae is a gregarious, endoparasitoids attack pupal stage of $C$. undecinmpunctata associated with aphids in vegetables crops.

\section{Total percentages of parasitism}

Results represented in Table 8 show the fluctuations of the total number of Coccinellids different immature stages parasitoids and total parasitism percentages of coccinellid species associated with aphids infesting wheat plants during the two seasons of study. The total 
Table 8. Seasonal abundance of Coccinellids different immature stages parasitoids and total percentages of parasitism on Coccinellid species associated with aphid infesting wheat plants in Belbis District, Sharkia Governorate during 2015-2016 and 2016- 2017 seasons

\begin{tabular}{|c|c|c|c|c|c|c|c|c|c|c|}
\hline \multirow{3}{*}{$\begin{array}{c}\text { Weekly date of } \\
\text { sample }\end{array}$} & \multicolumn{4}{|c|}{ Total number of } & \multirow{2}{*}{\multicolumn{2}{|c|}{$\begin{array}{l}\text { Total } \\
\text { asitism (\%) }\end{array}$}} & \multicolumn{4}{|c|}{ Corresponding means of } \\
\hline & \multicolumn{2}{|c|}{$\begin{array}{l}\text { Collected different } \\
\text { immature stages of } \\
\text { Coccinellid species }\end{array}$} & \multicolumn{2}{|c|}{$\begin{array}{c}\text { Emerged } \\
\text { parasitoids }\end{array}$} & & & \multicolumn{2}{|c|}{ Temp. $\left({ }^{\circ} \mathrm{C}\right)$} & \multicolumn{2}{|c|}{ RH (\%) } \\
\hline & 2016 & 2017 & 2016 & 2017 & 2016 & 2017 & 2016 & 2017 & 2016 & 2017 \\
\hline Feb., $1^{\text {st }}$ & 0 & 0 & 0 & 0 & 0.00 & 0.00 & 13.0 & 18.5 & 67.5 & 59.3 \\
\hline $2^{\text {nd }}$ & 0 & 0 & 0 & 0 & 0.00 & 0.00 & 14.9 & 15.3 & 57.2 & 63.3 \\
\hline $3^{\text {rd }}$ & 1 & 10 & 0 & 0 & 0.00 & 0.00 & 20.3 & 16.3 & 46.4 & 63.7 \\
\hline $4^{\text {th }}$ & 57 & 27 & 0 & 3 & 0.00 & 11.11 & 19.5 & 18.5 & 51.0 & 59.3 \\
\hline Total & 58 & 37 & $\mathbf{0}$ & 3 & 0.00 & 8.11 & & & & \\
\hline Mar., $1^{\text {st }}$ & 96 & 20 & 0 & 2 & 0.00 & 10.0 & 22.4 & 21.3 & 49.5 & 58.2 \\
\hline $2^{\text {nd }}$ & 66 & 33 & 10 & 0 & 15.15 & 0.00 & 20.5 & 19.9 & 48.7 & 63.3 \\
\hline $3^{\text {rd }}$ & 73 & 67 & 10 & 2 & 13.7 & 2.99 & 21.8 & 19.2 & 43.0 & 62.1 \\
\hline $4^{\text {th }}$ & 37 & 49 & 18 & 10 & 48.65 & 20.41 & 20.0 & 18.3 & 47.7 & 60.3 \\
\hline $5^{\text {th }}$ & 30 & 34 & 14 & 6 & 46.67 & 17.65 & 21.6 & 19.3 & 43.8 & 62.0 \\
\hline Total & 302 & 203 & 52 & 20 & 17.22 & 9.85 & & & & \\
\hline Apr., $1^{\text {st }}$ & 19 & 12 & 5 & 2 & 26.32 & 16.67 & 22.7 & 20.3 & 53.7 & 59.2 \\
\hline $2^{\text {nd }}$ & 10 & 7 & 0 & 0 & 0.00 & 0.00 & 26.4 & 20.0 & 40.7 & 53.9 \\
\hline Total & 29 & 19 & 5 & 2 & 17.24 & 10.53 & & & & \\
\hline General total & 389 & 259 & 57 & 25 & 14.66 & 9.65 & & & & \\
\hline
\end{tabular}

parasitism percentages showed one peak in the $4^{\text {th }}$ week of March with $48.65 \%$ and $20.41 \%$ in the tow seasons of study, respectively. Also the total number of emerged parasitoids recorded one peak at the same date by 18 and 10 parasitoids in the first and second seasons, respectively. The corresponding means of temperatures at these peaks were 20.0 and $18.3^{\circ} \mathrm{C}$ associated with $47.7 \%$ and $60.3 \% \mathrm{RH}$ in the tow seasons, respectively. The general percentages of parasitism during these seasons were $14.66 \%$ and $9.65 \%$, respectively.

Statistical analysis indicated that there were positive and highly significant correlations between weekly numbers of the aphid and numbers of coccinellid predators in the two seasons of study. The correlations between the total number of coccinellid predators and parasitoids were nigative in the first season $(\mathrm{r}=$ $0.0666)$ and $(\mathrm{r}=0.462)$ positive in the second one, being insignificant in both seasons.

\section{Conclusion}

The present work was conducted to study the seasonal abundance of coccinellid species and their insect parasitoids on wheat plants infested with aphids during two successive seasons 2015-2016 and 2016-2017. Seven predaceous species belonging to family Coccinellidae viz., $C$. undecimpunctata, C. septempunctata, C. 9- punctata, S. syriacus, $S$. interruptus, $C$. vicina isis and $C$. vicina 
nilotica were surveyed. The general relative densities of the predators were 33.33, 20.99, $19.44,12.35,7.41,4.01$ and $2.47 \%$ of the total number of predators, respectively. The highest total monthly counts of 292 predators, was obtained during March, followed by 86 predators during February in the first season. Five species of hymenopterous parasitoids belong to three families were emerged from collected coccinellid individuals. One egg parasitoid, Telenomus sp. belong to family Scelionidae. One larval parasitoid belong to family Braconidae. Three pupal parasitoids namely $T$. coccinellae, $T$. principiae and Tetrastichus sp. belong to family Eulophidae. The pupal parasitoid, T. coccinellae came in the first rank, represented by total parasitism $26.47 \%$ in the first season and larval parasitoid T. principiae was in the second one by $12 \%$.

The general total parasitism percentages of coccinellid species were 14.66 and $9.65 \%$ in the first and second seasons, consecutively.

\section{REFERENCES}

Abd El-Megid, J.E., M.A. El-Maghraby, K.A.A. Hammad and I.M. El-Baz (2007). Cereal aphids on wheat and their associated aphidophagous insect predators. Zagazig J. Agric. Res., 34 (3): 559-577.

Ahmed, U.S.R., M. Nadeem, K. Tarig, A. Ali, G. Naz, H. Badshan, A. Khan and S. Rahmen (2016). Seasonal abundance of aphids and their associated natural enemies with respect of planting dates in water crop of Pakistan. J. Agric. Environ. Sci., 16 (6): 1071-1078.

Brown, M.W. (2004). Role of aphid predator guild in controlling spirea aphid populations on apple in west Virginia, USA. Biol. Control, 29: 189-198.

El-Gepaly, H.M.H., M. El-Mandrawy, G. Karaman and A.H. Gharib (2018) Searching behavior of Coccinella undecimpunctata $\mathrm{L}$. (Coleoptera: Coccinellidae) and its parasitoid Tetrastichus coccinellae Kurd. (Hymenoptera: Eulophidae) Universal J. Res., 6 (1):153-158.

Gautam, R.D. (1994). Survival of aphidophagous ladybird (Coccinella septempunctata L.) on non-aphid hosts together with its natural emergency complex. Ann. Agric. Res., 15 (1): 71-75.

Hodek, I.A. and H. Honek (1996). Ecology of Coccinellidae. Kluwer Academic publishers, Dordrecht, 364.

James, D.D., K. Haider and A. Ghularm (2012). Seasonal abundance of aphids and aphidophagous insects in pecan. Insects, 3: 1257-1270.

Keiko, K.O., S. Hironori, T. Susumll and O. Takashi (1995). Synchronous growth of a parasitoid, Perilitus coccinellae, and leratocytes with development o the baire host, Coccinella septempunctata. Entomologica Experimentalis et Aplicata, 75 (2): 145-149.

Mohamed, A.H., P.J. Lester and T.O. Holtzer (2000). Abundance and effects of predators and parasitoids on the russian wheat aphid (Homoptera: Aphididae) under organic farming conditions in Colorado. Biological Control, Environ. Entomol., 29 (2): 360-368.

Obreycki, J.J. and T.J. Kring (1998). Predaceous Coccinellidae in biological control. Annul. Rev. Entomol., 43: 295-321.

Obreycki, J.J., J.D. Harood, T.J. Kring and R.J. Oneil (2009). Aphidophagy by Coccinellidae: agrecostems. Biol. Control, 51:244-254.

Richerson, J.V. and C.J. Deloach (2017). Some aspects of host selection by Perilitus coccinella. Ann. Entomol. Soc. Ame., 45 (4): 834-839.

Rizvi, N.H., T. Hussain, S.S. Ali, M.R. Rajut, M. Ahmed and A.R. Shakoori (1994). Comparative predatory behavior of larvae and adults of Coccinella septempunctata L. Proc. Pakistan Congr. Zool., 12: 285-289.

Sajioqi, A.U.R., K. Kanran and R.S. Sadur (2009). Integrated management of potatopeach aphid, Myzus persicae (Sulzer). Sarhad J. Agric., 25 (4) : 573-580.

Shalaby, F.F., A.H. El-Heneidy, A.A. Hafez and I.A. Bahy El-Din (2008). Seasonal abundances of common coccinellid species in some economic field crops in Egypt. Egypt, J. Agric. Res., 86 (1): 303-317. 
Shehta, A.M.A. (2008). Relationship between aphids and aphidophagous insects in ElKattara District. Ph.D. Thesis, Fac. Agric., Zagazig Univ., 210.

Silva, R.B., I. Cruz, M.L.C. Figueredo, A.G. Pereira and A.M. Penteado (2012). Occurrence and biology of Dinocampus coccinellae (Schrank, 1802) (Hymenoptera; Braconidae: Euphorinae) Parasitsing different species of Coccinellidae (Coleoptera) in Neotropical region. Bruz. J. Biol., 72 (1): 215-219.

Trouve, C., D. Thierry and M. Canard (2012). Preliminary survey of the lacewings (Neuroptera: Chrysopidae, Hemerobiidae) in agroecosystem in India, with phonological notes. Acta Zool. Hung., 48 (2): 359-369.

Vandereycken, A., D. Durieux, E. Joie, F. Francis, H. Francis and J. Verheggen (2015). Aphid species and associated natural enemies in field crop: wheat about the invasive ladybird Harmonia axyridis (Coleoptera: Coccinellidae). Faunistic Entomol., 68: 3-15.
Weber, D.C. and J.G. Lundgren (2009). Assessing the tropic ecology of the Coccinellidae : their roles as predators and as prey. Biol. Control, $51: 199-214$.

Youssif, M.A.I., SH.A.M. Ali and W.M.M. Helaly (2017). Cereal Aphid species (Homoptera: Aphididae) infesting wheat plants and their aphidophagous insects at ElKhattara District, Sharkia Governorate, Egypt. J. Plant Prot. and Path., Mansoura Univ., 8 (11): 581 - 589.

Youssif, M.A.I. (2019). Coccinellid species and their insect parasitoids in pear orchards at ElKhattara District, Sharkia Governorate, Egypt. J. Entomol. and Zool. Studies, 7 (2): 780-790.

Zeynep, Y.G., A. Ali and K. Turkan (2011). Seasonal occurrence of aphids and their natural enemie in Stasuman mandarin orchards in Zimir, Turkey. J. Entomol., 35 (1): 59-74.

\section{الوفرة الموسمية والكثافة النسبية لأتواع أبى العيد وطفيلياتها الحشرية على نباتات القمح بمركز

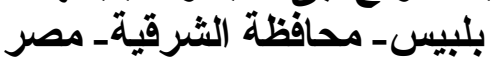

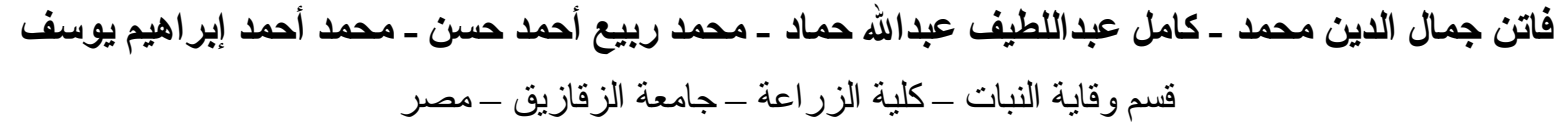

تم در اسة الوفرة الموسمية و الكثافة النسبية لانواع أبى العيد و الطفيليات الحشرية المصاحبة لها على نباتات القمح

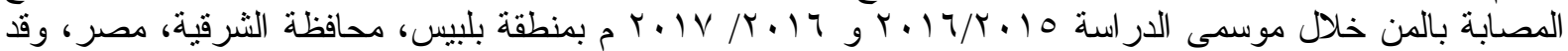

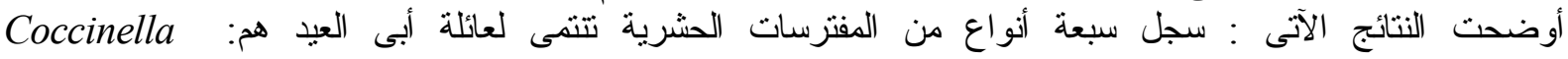
undecimpunctata L., Coccinella septempunctata L., Coccinella 9-punctata L., Scymnus syriacus Mars, Scymnus interruptus (Goeze), Cydonia vicina isis Cr. and Cydonia vicina nilotica Muls

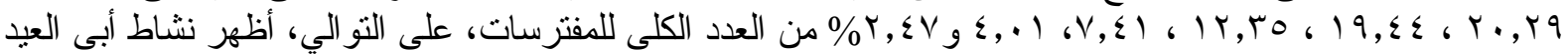

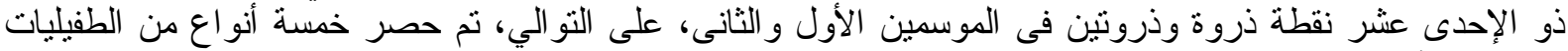

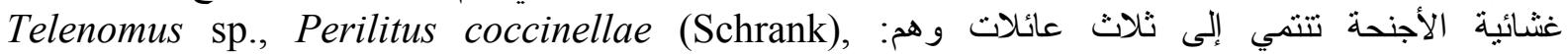
Tetrastichus coccinellae Kurd., Tetrastichus principiae Domenichini and Tetrastichus sp

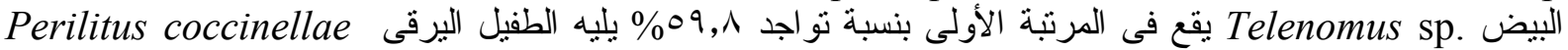
بنسبة ج,؛ (Schrank) للمفترسات و العدد الكلي للمن خلال موسمى الدر اسة. 